\title{
Educa

\section{MANAGEMENT OF SCHOOL INFRASTRUCTURE IN THE CONTEXT OF A No-FEE SCHOOLS POLICY IN RURAL SOUTH AFRICAN SCHOOLS: LESSONS FROM THE FIELD}

\author{
RAMODIKOE NYLON MARISHANE \\ University of Venda (South Africa)
}

\begin{abstract}
This study examines the management of school infrastructure in the context of the "no-fee schools" policy introduced in the South African education delivery system. Focusing on four rural schools, the study applied a qualitative method, which involved observation of infrastructure conditions prevailing at four selected schools and in-depth interviews held with their principals. The study has found that though the no-fee policy has come to relieve poor parents of the burden of paying school fees, it does not help schools in addressing their infrastructural challenges.
\end{abstract}

Keywords: no-fee school policy, school infrastructure, school funding, school management

Marishane, Ramodikoe N. (2013). Management of School Infrastructure in the Context of a No-Fee Schools Policy in Rural South African Schools: Lessons from the Fields. International Journal of Education Policy \& Leadership 8(5). Retrieved from www.ijepl.org .

\section{Introduction}

The provision of school funding in South Africa is a shared responsibility between the national government's Department of Education (DoE) - now called the Department of Basic Education (DBE) - and the provincial education departments (PEDs), of which there are nine in the country. While each PED is entitled to an equitable share of the national budget, a portion of which is used for making budget allocations for each school in a province, the DBE is responsible for setting norms and standards guiding such allocations. The norms and standards are intended to redress past apartheid injustices and iniquities in school funding between the rich and the poor school communities and are amended from time to time to sustain the process of closing the existing inequality gap. This is done by targeting schools in poor communities for more funding than their rich counterparts. To ensure that children from poor parent communities have the right to education as guaranteed by the South African Constitution (Act. No. 108, 1996), the national DoE has introduced a "no-fee schools" policy (South African Schools Act of 1996, 2006). The policy involves the exemption of poor parents from payment of mandatory school fees levied in schools in South Africa.

The no-fee policy is based on the amended National Norms and Standards for School Funding (NNSSF) (South African Schools Act of 1996, 2006). Section 35 of the amended NNSSF sets criteria for a fair and equitable distribution of state-allocated funding to public schools and provides for a system that places public school learners into national quintiles based on financial means of their parents.

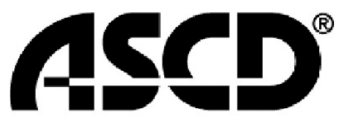

LEARN. TEACH. LEAD.
SEUISIMON FRASER UNIVERSITY THINKING OF THE WORLD

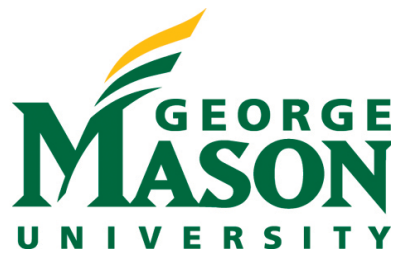


To ensure that state funding is allocated in a fair and equitable manner, a National Table of Targets (NTT) (South African Schools Act of 1996, 2009) has been developed to assist in this regard. Figure 1 shows an NTT for school funding allocations developed by the DoE and applied throughout the country to guide provinces in their allocation of funding to schools. The table shows the allocation per learner per quintile level occupied by a school. While column $\mathrm{A}$ in the table shows the different quintile levels occupied by schools in terms of their poverty, columns B and $C$ show allocation per learner and percentage of exemption from payment of school fees, respectively. Schools for the PEDs to direct 60 percent of their nonpersonnel and noncapital resources towards the poorest percentage of the schools in a province. This has led to a situation in which over 40 percent of schools have become no-fee schools (Republic of South Africa Department of Basic Education, 2010). It follows, therefore, that the no-fee schools policy aims at ensuring that all children, regardless of their socioeconomic background, enjoy free access to quality education in their communities (Giese, Zide, Koch, \& Hall, 2009). In this manner, it is lauded as being responsive to the constitutional imperative of the right to basic education (Republic of South Africa Department of

Figure 1

\begin{tabular}{|c|c|c|c|c|c|c|c|}
\hline \multirow[b]{2}{*}{ A } & & \multicolumn{2}{|l|}{2010} & \multicolumn{2}{|l|}{2011} & \multicolumn{2}{|l|}{2012} \\
\hline & & $\mathrm{B}$ & $\mathrm{C}$ & $\mathrm{B}$ & $\mathrm{C}$ & $\mathrm{B}$ & $\mathrm{C}$ \\
\hline NQ1 & 30.1 & $\mathrm{R} 855$ & $100 \%$ & R901 & $100 \%$ & R943 & $100 \%$ \\
\hline NQ 2 & 27.5 & R784 & $100 \%$ & R826 & $100 \%$ & $\mathrm{R} 865$ & $100 \%$ \\
\hline NQ 3 & 22.5 & R641 & $100 \%$ & R675 & $100 \%$ & R707 & $100 \%$ \\
\hline NQ 4 & 15.0 & R428 & $67 \%$ & $\mathrm{R} 451$ & $67 \%$ & R472 & $67 \%$ \\
\hline NQ 5 & 5.0 & $\mathrm{R} 147$ & $22 \%$ & $\mathrm{R} 155$ & $22 \%$ & $\mathrm{R} 162$ & $22 \%$ \\
\hline Overall & 100.00 & R571 & $89 \%$ & R602 & $89 \%$ & R630 & $89 \%$ \\
\hline \multicolumn{2}{|l|}{ No fee threshold } & \multicolumn{2}{|l|}{ R784 } & \multicolumn{2}{|l|}{ R826 } & \multicolumn{2}{|l|}{$\mathrm{R} 865$} \\
\hline \multicolumn{2}{|l|}{ Small schools: } & \multicolumn{2}{|l|}{ R21 000} & \multicolumn{2}{|c|}{ R22 113} & \multicolumn{2}{|l|}{ R23 152} \\
\hline National fixed am & & & & & & & \\
\hline
\end{tabular}

National Table of Targets for School Allocation (2010-2012)

Source: Department of Education, 03 December 2009 (South Africa, 2009a)

at the top of the table-namely, those in quintiles 1 to 3-are declared by the Minister of Education as "no-fee schools," and parents of the learners attending these schools are exempted from payment of school fees (Bentley, 2006) because of their poor socioeconomic background. In other words, school funding is skewed in favor of poor school communities. The state pays $100 \%$ of fees allocated per learner in these schools.

Guided by the NNSSF, each PED allocates funding to its schools in the province. This NNSSF-based allocation has made it possible
Basic Education, 2010).

The allocation of funding to schools in South Africa is in line with decentralization policies applied in many parts of the world (Fullan \& Watson, 1999; Caldwell, 2005; The World Bank, 2007); that is, to improve schools, decision-making authority and the necessary financial resources are handled at the school level. This includes the creation of a situation where school-level actors, such as school governing bodies, parents and principals, have discretion to use their allocated funds to improve school infrastructure. The 
closer proximity of these actors to their schools would hopefully enable them to have a clear picture of the state of the schools' physical facilities and take appropriate remedial actions when the need arises. What this implies in the no-fee schooling context is that, though poor parents are relieved from paying school fees, they still enjoy the freedom to channel the state funding into improving their schools and catch up with the previously advantaged schools. The current situation in the no-fee schools is not like that, however, as this study will show. A study recently commissioned by the state shows that despite the state's efforts in bringing about equity in education spending per learner, "the quality of physical assets and infrastructure at school level remains highly unequal. There are still many schools without toilets, electricity, desks, and chalkboards" (Republic of South Africa National Planning Commission, 2010, p. 14).

\section{Educational Value of School Infra- structure and Its Relation to School Funding}

School infrastructure refers to the physical teaching and learning environment. In the South African context, it includes the provision of "water, sanitation, suitable classrooms, and essential specialist rooms, such as libraries and laboratories" (Republic of South Africa Department of Education, 2007). This environment adds value to educational achievement as the following examples indicate. First, school infrastructure is one of the five dimensions contributing to quality education (UNICEF 2002, 2005). Second, research-based evidence shows a positive link between learning outcomes (output) and the physical environment (input) in which teaching and learning (input) take place (Bullock, 2007; Higgins, Hall, Wall, Woolner, \& McCaughey, 2005; Earthman, 2004). Specifically, studies based on data collected from 14 sub-Saharan African countries (Lee, Zuze, \& Ross, 2007) show that high learner achievement occurs where schools have access to such facilities as librar- ies, equipment, running water, electricity, and playgrounds, among others. Third, in a study focusing on the effects of school infrastructure on learner attendance and dropout rates, Branham (2004) found that learners are less likely to attend schools in need of structural repair, schools that use temporary structures, and schools that have understaffed janitorial services. Last, while good school infrastructure enhances access to education, poorly maintained infrastructure excludes learners (Council for Scientific and Industrial Research, 2011). It follows from these studies that school infrastructure plays an important role in education delivery. What this suggests is that, when schools are funded, consideration has to be given to the maintenance aspect of the infrastructure and adjust funding allocations accordingly.

\section{How Money Enters a No-Fee School}

In the case of no-fee schools, money that schools receive comes mainly from state allocations (South African Schools Act of 1996, 2010). This money enters the school in two ways-namely, direct allocation and indirect allocation. Direct allocation refers to money deposited into the school's bank account to cover the school's operational costs. Indirect allocation refers to the money allocated to the school but held in trust by the Department (DBE) for the purchase of textbooks and other learning and teaching support materials (LTSM) on behalf of the schools. Schools are informed in advance of their total allocations for a school financial year and are strictly reminded about conditions attached to the use of the allocated money and to stick to the conditions (South African Schools Act of 1996, 2009). These conditions are outlined in Figure 2 and in section 4 . The table lists the categories of items for which a school must spend the state-allocated funding. Any deviation from the list without prior special approval of a provincial head of education department is not allowed. As it can be noted from the table, the allocation excludes money for major infrastructural projects, such as 
erection of school buildings. The implication of this exclusion is that the DoE regards the provision of infrastructure as its main responsibility.

\section{Conditions Attached to Funding Al- located to No-Fee Schools}

There are two sets of conditions attached to the state funding allocated to no-fee schools. The first set of conditions relates to the actual release of the state-allocated funding and involves the requirement for a school to submit to the PED its annual budget for nonpersonnel recurrent expenditures and an audited annual financial statement (Thwala, 2010) as a precondition for the release of funding. In addition, schools are expected to keep records of all funds they received and spent. This includes records of financial transactions schools made, their assets and liabilities, and how materials and services were used for inspection by the head of department in the PED. The second set of conditions relate to the actual expenditure of the state-allocated funding once such funding is released to the school. These conditions appear in the form of prescripts stipulating specific purposes for which money should be exclusively used (Limpopo Provincial Government Department of Education, 2009). Such purposes include the following, as prescribed by paragraph 114 and 115 of the South African Schools Act of 1996 (1996):

- Payment for improvements and repairs on immovable capital.

- Payment of services.

- Purchases of educational materials and equipment for the school, excluding those that are provided by the Department (DBE).

Strict conditions are imposed on the use of funds allocated by the state to the schools. For this reason, PEDs have promulgated regulations (Gauteng Provincial Government Department of Education, 2010) guiding schools on the use of the funds in line with the provisions of the no-fee schools policy to ensure that funds transferred to schools are used efficiently and only for the purpose for which

Figure 2

Guidelines and Prescripts for the Use of Direct and Indirect School Allocations

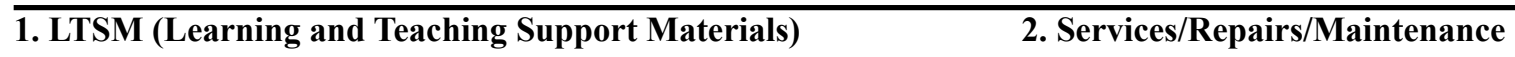

\begin{tabular}{ll}
\hline Textbooks & Security \\
School stationery & Pest control and sanitation \\
Office stationery & Traveling (Government rates apply) \\
Library resources & Electricity/telephone/water \\
Library stationery & Fencing \\
Laboratory equipment and specialized rooms & Sports \\
\hline
\end{tabular}

Sources: Limpopo Provincial Government, Department of Education (South Africa, 2009b) and Gauteng Provincial Government, Department of Education (South Africa, 2010d) 
they are intended. In terms of the policy, for instance, schools are not allowed to use their allocations for capital projects, such as the construction of building structures or major renovations. This responsibility is reserved for the Department of Education (DoE). However, given the prevailing infrastructure backlogs in the country (Motala \& Sayed, 2009) the DoE faces major challenges in the provision of school buildings and other basic services. It can, therefore, not meet its constitutional obligations.

\section{Balancing the Need, Provision, and Sustainability of School Infrastructure in a No-Fee School Through Effective Management}

In a situation where a no-fee school cannot have access to any additional funding apart from funding provided under the NNSSF, more pressure is put on school managers to manage infrastructure effectively. Effective infrastructure management in schools may be understood as the management of the provision, use, maintenance, and disposal of a school's physical resources (equipment, buildings, and grounds), with due consideration given to their educational value and value for money principles of economy, efficiency, and effectiveness. In this regard, effective infrastructure management practically involves the creation of structures, policies, systems, and plans for effective infrastructure management.

The no-fee school situation puts pressure on school managers to clearly identify pressing school infrastructural needs and be creative in generating financial strategies to satisfy them. In addition, the situation also demands that both the desired and the existing infrastructure be well maintained to sustain its educational value. A recent study conducted in South Africa (The Mvula Trust, 2010) has found that, while some schools showed lack of knowledge of how to take care of their sanitary facilities, others had their sanitary facilities vandalized, left dirty, blocked, or even locked, making it difficult for learners to ac- cess and use them. This suggests a need for effective infrastructure management in schools.

\section{No-Fee Policy Implications for Schools}

At the school level, the practical implications of the provisions of the no-fee policy include the following:

- Schools are exempted from levying school fees (directly or indirectly) because they serve poor school communities.

- Schools are allocated more funding than before the introduction of the policy in order to meet most of their basic needs.

- The school funding allocation is guided by the NNSSF to ensure equitable funding distribution among schools.

- Schools are given powers to manage their allocated funding in accordance with legal prescripts provided by provincial education departments (PEDs) to safeguard funds against mismanagement.

- Financial management powers given to schools are balanced against the PED's demand for accountability for the expenditure of the funds allocated to a school.

\section{Aim of the Research}

In terms of the law (South African Schools Act of 1996, 2009), no-fee schools are not permitted to levy school fees. In addition, no public school is allowed to use state allocations to fund capital projects. Despite this, school managers and governing bodies are required to administer and control school property, buildings, and grounds. Against this background, this research sought to examine how school principals managed school infrastructure in the context of the no-fee schools policy.

\section{Methodology}

The study followed a qualitative approach, which involved data collection through observations of physical facilities and in-depth interviews held with school principals of four purposively selected schools in one circuit in 
Limpopo Province, South Africa. The sample consisted of two primary schools and two secondary schools. The schools were selected on the basis of the appearance of their physical facilities (buildings, grounds, sanitation, and water provision) and the fact that they were all declared no-fee schools and were located in four rural villages. I was granted permission to interview the principals of the four schools after the purpose of the study was stated and confidentiality of the interviews was assured. I visited the schools and worked out their profiles based on personal observations that I noted.

\section{School Profiles}

School A is an old secondary school that was renovated a few years ago by a private company. It had a sufficient number of classrooms to accommodate over 900 students until a year ago when one block of classrooms had its roof blown away by a severe storm. Two additional classrooms were also severely damaged. The school has a well-resourced science and biology laboratory, a computer center, an administration office, a staff room, two hostels for male and female learners, and pit toilets that have just been renovated. The school is well fenced-off and the grounds are kept clean by a school caretaker who is paid by the school governing body (SGB) for services rendered. The hostel buildings look old and appear to be in need of renovation and repair. The school has enough running water to be shared with the hostel community. The school has an open sports field that is shared with the community.

School B is a primary school with an enrollment of 89 learners. It is well fenced-off and has two blocks of classrooms. Two classrooms had their roofs damaged by a storm a year ago. The SGB reported the matter to the PED, which provided the school with one mobile classroom. Apart from the classrooms, there are no other buildings. One of the remaining classrooms is used as both an office and a staffroom. The grounds are not well kept. There is no sports field where learners can participate in extramural activities.

School C is one of oldest primary schools in the area and has an enrollment of over 500 learners. The school has a shortage of classrooms and an immense overcrowding problem. The school has enough toilets for both learners and teachers. It has an office and a staffroom. Water has been connected to the school from the main community line. The grounds are clean. The school shares its sports facilities with the community.

School D is a secondary school which appears to be a victim of continued vandalism. The school has two blocks of classrooms. One block of six classrooms was vacated after a storm damaged the roof and furniture; a new block was then built for the school by the PED. Enrollment has dropped dramatically in this school from over 220 students to 178 .

\section{Procedure for Data Collection and Analysis}

\section{Data Collection}

A semi-structured interview schedule with questions focusing on school infrastructure management was prepared to serve as a datagathering tool for this study. This was followed by four one-hour interviews which were recorded for subsequent data transcription.

\section{Data analysis}

A thematic analysis was selected on the basis of its flexibility as a suitable qualitative analytic method for this study. I followed a stepby-step approach to thematic analysis of my data as advocated by Braun and Clarke (2006). This approach assisted me in identifying, analyzing, and reporting on patterns (themes) after reading the transcripts from the recorded data. Considering the view that "not all themes are equally important" (Ryan \& Bernard, 2003, p. 103), I marked and sorted commonly applied expressions and repetitions emerging from the themes and subthemes, ap- 
plying a cutting-and-pasting coding technique to process the transcribed text. The technique involves identifying expressions that appear to be important and then arranging them in categories (Stewart, Shamdasani, \& Rook, 2007). In applying the technique, I developed a table with four key words derived from my research questions as reflected in my interview schedule: impact, response, capacity, and support. I used these key words to develop categories for organization of transcribed expressions. Transcribed expressions were first color-coded and then cut, pasted, and sorted according to the key words (categories). In this manner, I could identify the following four themes:

1. Impact of school infrastructural problems on teaching and learning. The theme consisted of two subthemes: infrastructurerelated problems and teaching and learning, and contained expressions such as "overcrowding made group work difficult," "lack of concentration in mobile classrooms with no air conditioners," "learners throwing things out of broken windows during lessons," "theft of teaching and learning support materials," and "learners running into the village for drinking water during teaching and learning periods."

2. Schools' response to infrastructural problems. This theme was constituted by statements such as "We improvise where possible," "We try to fundraise," and "Learners are moved to the lab during exams."

3. Capacity for management of school infrastructure. The theme consisted of participants' expressions on such management issues as training, policymaking, planning, and maintenance.

4. PED support for schools experiencing infrastructural problems. The theme emerged from the participants' expression of support from the district and was represented by such phrases as limited or no school visits, poor provisions of mobile classrooms, and delays in responding to emergencies.
The four themes presented resulted from several revisions of the transcribed expressions that constituted them. This was intended to ensure coherence and internal consistency of the themes, which enabled me to generate a report on the results.

\section{Results}

The results of the study are presented according to the four identified themes.

\section{Impact of School Infrastructural Problems on Teaching and Learning}

All the schools covered in this study experienced infrastructure problems, which varied from school to school. Problems which were identified include overcrowding, neglect, lack of running water, sanitation, lack of security, vandalism, and poorly maintained school grounds, equipment and buildings. With the exception of School D, all the schools experienced overcrowding, which affected effective teaching and learning. At School B, for example, learners from two different grades were cramped in one mobile classroom with no airconditioning. The school principal voiced his frustration in this way: "The mobile classrooms are not comfortable. They are very hot in summer and very cold in winter. You cannot install air conditioners because these facilities do not belong to the school. The Department (PED) has hired them from service providers."

In addition to this, lack of security was a common problem among the four schools. At School A, the main problems were overcrowding and lack of security. Over 30 computers were stolen from the school a few weeks after they were delivered. At School B, introductory technology lessons that had just started had to be abandoned. Though the school has a wellequipped computer laboratory, computers were stolen owing to lack of strong security, depriving learners of important learning resources.

At School C, one of the treasured buildings consisting of five classrooms had its roof 
blown away by a storm. This gave rise to a challenge of overcrowding in classrooms. The principal of the school explained: "Because we are not allowed to use the Norms and Standards funds for major renovations, parents agreed with the governing body at a meeting to contribute money towards renovation of the roof. We collected the money and notified the district office. The district office said, 'Refund the parents! You are a no-fee school and have no right to levy funds from poor parents.' The project stopped and we are now waiting for the unknown."

At School D, one block of classrooms was vacated after the roof was damaged by a storm; learners were then accommodated in the new block that houses the principal's office. Most of the classrooms, including those in a new block that was erected four years ago, have broken windows. The fence is broken and the holes in it enable goats to roam the school grounds. The pit toilets are old and not healthy to use. The state of the sports fields is so bad that learners do not use them at all. The school grounds are unclean and littered with paper and other refuse. The school has no security.

\section{Schools' Response to Infrastructural Problems}

Apart from reporting some of their problems to the PED, the schools in the study responded to their specific infrastructural problems in different ways. Since five classrooms were damaged by a storm at School A, furniture was moved to the school's dining hall, hostel, and other classrooms. While some learners were relocated to the school dining hall, learners in the natural science classes were accommodated in the school's technology and science laboratories. This led to overcrowding in the science laboratory, making it difficult for other learners to use the facility. During examinations, the local church was used as a temporary examination facility to accommodate the large number of learners. Requests for financial donations from the private sector were attempted but were not successful. Lack of knowledge of fund-raising be- came a major barrier, as the principal explained: "You see, we tried our best here. We wrote letters to various organizations requesting assistance, hoping that we would get money for the roof, but all the replies were 'regrets."'

School B is the poorest of these schools. The school does not have security, running water, sports facilities, an administration building, or vital resources, such as photocopiers. During the interviews, the principals of both School B and School D gave the impression that the whole situation was beyond their control. They were to wait for the PED to do everything for them. For example, no attempts were made to repair the damaged block, repaint the walls, or replace broken windows at School D. The infrastructure there appeared to be in a state of neglect. The school has an expensive photocopying machine, but because of poor maintenance, the machine is not in a working condition and the school has to rely on the neighboring primary school for photocopying services during the examinations.

The SGB at School $C$ reported the damage caused to their school building to the PED through the local circuit office. After waiting for three months with no response, the school decided to take action. The principal said: "We had enough money from the Norms and Standards, but as you know, we are not allowed to use the money for buildings. We are disempowered. The SGB and parents agreed to contribute R50 per learner towards renovation of the old building. Many parents had already contributed when we informed the Department (PED) about the project. The circuit manager said, 'No! You are a no-fee school. You are not allowed to raise money from the poor parents. You must refund them.' We did, and the project stopped."

\section{Capacity for Management of School Infrastruc- ture}

During the interview with the four school principals, it emerged that schools lacked the 
necessary infrastructure-management capacity, as reflected by the following aspects:

1. Structures for managing infrastructure. The schools did not have committees for managing the school's physical facilities (buildings, grounds, and equipment).

2. Policies on school infrastructure management. The four schools did not have policies for acquisition, use, and maintenance of infrastructure.

3. Plans for infrastructure development. Though principals had problems with their schools' state of infrastructure, they appear to have no plans of dealing with the problems, apart from reporting problems to the PED.

4. Capacity to Deal with Infrastructure related problems. The school principals in this study had not received any training in areas such as asset management, risk management, and fund-raising to enable them to deal with infrastructure-related problems.

\section{PED Support for Schools Experiencing Infra- structural Problems}

In the four schools studied, the support given by the PED to the affected schools appeared to follow the same pattern. The school principals would report their needs for infrastructure, and then wait awhile for the PED officers to visit the school to assess the need for a new infrastructure or renovations before real assistance arrived. As the principal of School C stated: "Usually it takes numerous follow-up visits to the circuit office to elicit a response. You are told that you are not the only one on the list. Then there is a story or two about Department of Public Works and mobile toilets."

In the case of emergency situations arising from natural disasters affecting school buildings, assistance comes in the form of mobile classrooms. Though these temporary structures offer a certain measure of relief, they have their own problems, as one of the principals indicated: "The problem with mobile classrooms is that in winter they are very cold and in summer they are extremely hot. You cannot install any electrical equipment like heaters or air conditioners in these classrooms because they are temporarily hired structures that do not belong to the school. Besides, they are smaller than the normal classrooms and makes movement very difficult when teaching learners."

\section{Discussion: What Lessons can School Leaders Draw From Infrastructure Management in No-Fee Schools?}

There are several lessons drawn from this study. These lessons revolve around leadership in the area of school infrastructure management in a no-fee school setting and can be presented in the following ways.

\section{Effective School Infrastructure Management Requires Effective School Leadership.}

Effective infrastructure management (development of school-based infrastructure management structures, policies, and plans for maintenance and renovations of the school's physical facilities) is important for school improvement. This requires effective school leadership. Studies show that school leadership is pivotal in determining the success of school improvement (Leithwood, 2002). Principals of the no-fee schools studied in this research appeared to be helpless and heavily reliant on the PED for the management of infrastructure. This stands in stark contrast to the purpose of school-based management-empowerment of the local school community. While it is acknowledged that the SGB is responsible for the school's finances and assets as expressed by Section 36 of the South African Schools Act of 1996 (1996), the leadership of the school principal is critical for the functionality of the SGB in this regard. To ensure that the decisions taken on infrastructure improvement align with the school's vision, the SGB looks to the principal for professional guidance and direction. This is because focusing on infrastructure management as well as 
management of other educational resources needed for effective functioning of the school is a key technical dimension of school leadership (Marishane, 2011). What this suggests is the need for the PED to invest in training school principals and SGBs of no-fee schools in effective school infrastructural management.

\section{Sustainable Funding for School Infrastructure Requires a State-School Partnership.}

Reliance on state-allocated funding for infrastructure provisioning in no-fee schools without additional funding from other sources cannot be sustained in the long run. No-fee school funding is an interim measure to redress inequalities and existing backlogs. Studies show us that just as the state cannot control schools alone (Marishane, 1999), it cannot shoulder the responsibility of funding education on its own (Nakpodia, 2011). In other words, while the state has a constitutional obligation to fund education and provide the necessary resources to the school (South African Schools Act of 1996, 1996) the school community should support the state in this regard. It is for this reason that Section 36 of the South African Schools Act of 1996 (1996) demands SGBs to seek ways of supplementing the resources supplied by the state in order to improve the quality of education provided by the school to all its learners. This suggests that no-fee schools should embark on a fundraising drive and, to strengthen partnerships between the state and the no-fee schools, the PED should invest in building and developing the capacity of SGBs and principals in the area of fund-raising.

While one might acknowledge increased funding for poor schools is an incentive for their improvement, research shows that financial incentives are less easy to sustain than nonfinancial incentives (Hite \& De Grauwe, 2008). This builds a strong case for leadership capacity building to accompany state funding allocations to no-fee schools. Money alone will not improve no-fee schools.

\section{School Infrastructural Needs Should be In- cluded in School Strategic Plans.}

The infrastructural needs of schools should be included in the schools' strategic development plans aimed at improving their conditions, so that school budgeting can be informed by such plans. These plans should be shared with the PED and form one of the criteria for state allocations to schools (Marishane \& Botha, 2004). The inability of school principals in this study to deal with natural infrastructure management in the event of natural disasters shows their need not only for training in disaster management, but also for having plans in place for dealing with challenges resulting from such situations. Research shows that "planning is vital for making education responsive to dynamic local and global conditions" (Asian Development Bank, 2010, p. 7). In addition to this, no-fee school principals and their SGBs should be empowered to use their budgets based on the strategic plans to meet their pressing infrastructural priorities and satisfy their school needs in this regard, particularly in the event of emergencies. For this, the PED should focus on school-based strategic development planning for SGBs to enhance their leadership capacity for school improvement in line with the provisions of Section 19 of the South African Schools Act of 1996 (1996).

\section{Conclusion}

There are serious challenges in the management of school infrastructure in rural areas because of four major barriers emerging from this study. The first barrier relates to the fact that schools declared no-fee schools are not allowed to levy school funds. Even where parents are prepared to support their schools financially, they are not permitted to do so. The second barrier relates to the restrictions imposed on the funding allocated to the schools through NNSSF. This implies that even though the school may have enough money to cover building costs in the case of emergencies, such money cannot be used to address 
the emergencies owing to the strict conditions attached to the funding. The third barrier relates to lack of fund-raising skills for school managers. This implies that, even though it is found that the state alone cannot fund education (Marishane, 2003), many school principals have not received training on fundraising. The last barrier relates to lack of knowledge on infrastructure management. It follows from the study of these barriers that, though the no-fee school policy introduced in the education delivery system relieves poor parents of the burden of paying school fees, it does not relieve schools of the pressure they experience in managing their infrastructure.

\section{References}

Asian Development Bank. (2010). Guidance note: Education sector risk management. Manila, Philippines: Author.

Bentley, B. (2006, February 28). No fee schools [blog post]. Retrieved from School Management S.A. website:

http://schoolmanagement.blogspot.com

Branham, D. (2004). The wise man builds his house upon the rock: The effects of inadequate school building infrastructure on student attendance. Social Science Quarterly (85)5.

Braun, V., \& Clarke, V. (2006). Using thematic analysis in psychology. Qualitative Research in Psychology, 3(2), 77-101.

Bullock, C. C. (2007). The relationship between school building conditions and student achievement at the middle school level in the Commonwealth of Virginia (Unpublished doctoral dissertation). Virginia Polytechnic Institute and State University, Blacksburg.

Caldwell, B. (2005). Education policy series: School-based management. Paris: International Institute for Educational Planning; and Brussels, Belgium: International Academy of Education.

Constitution of the Republic of South Africa, Act No. 108 of 1996 (Government Printing Works 1996).
Council for Scientific and Industrial Research (CSIR), CSIR Built Environment. (2011). Focus on CSIR research in improved sanitation infrastructure at schools. Retrieved from www.csir.co.za/Built_environment/pdfs/scho ol_sanitation infrastructure May2011.PDF

Earthman, G. I. (2004). Prioritization of 31 criteria for school building adequacy (Executive Summary). Baltimore: American Civil Liberties Union Foundation of Maryland. Retrieved from National Education Access Network website: www.schoolfunding.info/policy/facilities/AC LUfacilities report1-04.pdf

Fullan, M., \& Watson, N. (1999). School-based management: Reconceptualizing to improve learning outcomes. Toronto: Ontario Institute for Studies in Education, University of Toronto.

Gauteng Provincial Government Department of Education. (2010). Resource allocations for public ordinary schools, including "no-fee schools" for 2010/2011. Johannesburg: Author.

Giese, S., Zide, H., Koch, R., \& Hall, K. (2009). A study on the implementation and impact of the no-fee and school fee-exemption policies. Plumstead, South Africa: The Alliance for Children's Entitlement to Social Security.

Higgins, S., Hall, E., Wall, K., Woolner, P., \& McCaughey, C. (2005). The impact of school environments: A literature review, The Centre for Learning and Teaching, School of Education, Communication and Language Science, University of Newcastle. Retrieved from Centre for British Teachers (CfBT) website: www.cfbt.com/PDF/91085.pdf

Hite, S. J., \& De Grauwe, A. (2008). Capacity development in educational planning: Learning from successes and failures. Paris: International Institute for Educational Planning (IIEP). 
Lee, V. E., Zuze, T. Z., \& Ross, K. N. (2005). School effectiveness in 14 sub-Saharan African countries: Links with 6th graders' reading achievement. Studies in Educational Evaluation, 31(2-3), 207-246.

Leithwood, K.A. 2002. Organizational conditions to support teaching and learning. In Hawley, W. \& Rollie, D. (Ed's), The keys to effective schools. Thousand Oaks, CA: Cowin Press, 97-110.

Limpopo Provincial Government Department of Education. (2009). Prescripts for management of school funds in public schools. Polokwane, South Africa: Author.

Marishane, R. N. (1999). Partnership in school governance: Foundation for reform and restructuring (Unpublished master's thesis). University of South Africa, Pretoria.

Marishane, R. N. (2003). Decentralisation of financial control: An empowerment strategy for school-based management (Unpublished doctoral thesis). University of South Africa, Pretoria.

Marishane, R. N. (2011). School leadership in a changing context: A case for school-based management. Pretoria, South Africa: Van Schaik.

Marishane, R. N., \& Botha, R. J. (2004). Empowering school-based management through decentralised financial control. Africa Education Review, 1(1), 95-112.

Motala, S., \& Sayed, Y. (2009, August) "No fee" schools in South Africa (Policy Brief No. 1). Consortium for Research on Education, Access, Transitions, and Equity (CREATE). Retrieved from CREATE's website: www.create-rpc.org/pdf documents/South_A frica Policy Brief 1.pdf

Nakpodia, E. D. (2011). Integrative funding and effective implementation of universal basic education programme in Central Senatorial District of Delta State, Nigeria. Journal of Economics and International Finance, 3(3), 157-167.
Republic of South Africa Department of Education. (2007). Strategic Plan 2007-2011. Pretoria: Author.

Republic of South Africa Department of Basic Education. (2010). Education for all (EFA): 2009 country report: South Africa. Pretoria: Author.

Republic of South Africa National Planning Commission. (2010). Diagnostic overview. Pretoria: Author.

Ryan, G. W., \& Bernard, H. R. (2003). Techniques to identify themes. Field Methods, 15(1), 85-108.

South African Schools Act of 1996, Act No. 84 of 1996, Pub. No. 1867 (Government Gazette, Government Printing Works 1996).

South African Schools Act of 1996, Notice No. 868, Amended National Norms and Standards, Pub. No. 29178 (Government Gazette, Government Printing Works 2006).

South African Schools Act of 1996, Notice No. 1138, Amended National Norms and Standards for School Funding, Pub. No. 32722 (Government Gazette, Government Printing Works 2009).

South African Schools Act of 1996, Notice No. 706, National Norms and Standards: Call for Comments on Draft Amendments to the National Norms and Standards for School Funding, Pub. No. 33450 (Government Gazette, Government Printing Works 2010).

Stewart, D. W., Shamdasani, P. N., \& Rook, D. W. (2007). Focus groups: Theory and practice (2nd ed.). Thousand Oaks, CA: Sage.

The Mvula Trust. (2010). Annual Report 2009/ 2010. Retrieved from

http://mvula.org.za/images/uploads/annual_r eport2010.pdf

The World Bank. (2007). What is school-based management? Washington, DC: Author.

Thwala, S. M. (2010). The management of "no fee" schools in Mpumalanga: A case study of selected secondary schools (Unpublished dissertation). University of South Africa, Pretoria. 
UNICEF. (2002). Quality education for all:

From a girl's point of view. New York: Author.

UNICEF. (2005). Gender achievement and prospects in education: The GAP report (Part 1). New York: Author.

IJEPL is a joint publication of the Association for Supervision and Curriculum Development, the Faculty of Education at Simon Fraser University, and the College of Education and Human Development at George Mason University. By virtue of their appearance in this open access journal, articles are free to use, with proper attribution, in educational and other non-commercial settings 90 days after initial publication. Copyright for articles published in IJEPL is retained by the authors. More information is available on the IJEPL Web site: http://www.ijepl.org 